\title{
Proceeding
}

Supplementary Issue: Spring Conferences of Sports Science. Costa Blanca Sports Science Events, 14-15 June 2019. Alicante, Spain.

\section{Anthropological providing educational services to children with special educational needs}

\author{
IGOR GRYGUS ${ }^{1}$, OLHA NAGORNA ${ }^{1}$, ANZHELA NOGAS ${ }^{1}$, WALERY ZUKOW ${ }^{2}$ \\ ${ }^{1}$ National University of Water and Environmental Engineering, Rivne, Ukraine \\ ${ }^{2}$ Nicolaus Copernicus University in Torun, Torun, Poland
}

\begin{abstract}
In pedagogical circles always having the discussion concerning the effectiveness, feasibility of one or another form of training. A difficult issue is the differentiation of the psycho-medico-pedagogical commissions on the selection of programs and learning, educational institution. Thus, the actual research of the education of children with special educational needs on the example of educational institutions of Rivne. Research objective: to study the formation of the system of education for children with special educational needs. Research objectives: 1. To conduct a systems analysis of the scientific literature on the topic of research. 2. Examine the network of inclusive schools in Rivne. 3. Analyse the provision of educational services to children with disabilities in Rovno educational and rehabilitation centre "Special Child". 4. Synthesize statistical information and reveal the dynamics of qualitative and quantitative nosology of children with disabilities in schools. Research methods: theoretical analysis of literary sources, summarizing statistical data of educational institutions of city Rivne. Analysis of the changes of the quantitative and qualitative composition of the inclusive class allows you to infer that children with special educational needs enrolled in inclusive classrooms for nosology violations observed a certain imbalance. So, the advantage for inclusive education is given to students with cognitive and reports violations. Almost twice smaller number of children in violation of the locomotor and hearing. Significantly fewer students with disorders and mental retardation. Not specified such diagnoses as an autistic spectrum disorder and down syndrome. Obviously, these were incorporate into the category of violations. Data analysis allows us to draw conclusions that the implementation of the State programme concerning the staffing system of inclusive education is effective, but does not provide the full needs of schools in all members of the interdisciplinary team of rehabilitation support a child with special educational needs. In particular, not all educational institutions are equipped properly to ensure the needs of the child and the implementation of a full-fledged correction support; not organized by specialized facilities, inadequate rehabilitation equipment, special furniture for pupils with impaired function of the musculoskeletal system; missing tiflocorrection means, tiflopedagog; the physical therapist is not available in all schools.
\end{abstract}

\footnotetext{
Corresponding author. Nicolaus Copernicus University in Torun, Torun, Poland. http://orcid.org/0000-0003-2856-8514

E-mail: w.zukow@wp.pl

Supplementary Issue: Spring Conferences of Sports Science. Costa Blanca Sports Science Events, 14-15 June 2019. Alicante, Spain.

JOURNAL OF HUMAN SPORT \& EXERCISE ISSN 1988-5202

(c) Faculty of Education. University of Alicante

doi:10.14198/jhse.2019.14.Proc4.48
}

S852 | 2019| Proc4 | VOLUME 14

C 2019 University of Alicante 
Conclusions. The analysis of this problem leads to the following conclusions: in the scientific and methodical sources analysed the effectiveness and usefulness of various forms of educational services for children with special needs. Analysis of inclusive classes shows positive dynamics of this process and increase the number of pupils with impaired psychophysical development in secondary schools. Experience of the Rivne training and rehabilitation centre "Special Child" and confirms that as a result of the implementation of inclusive education in school has increased the number of children with complex disabilities development, accompanied by intellectual retardation and existing disabilities. Therefore, special educational institutions should be multiprofile that will provide your child with special educational needs education and obtaining proper corrective rehabilitation support. Due to the focused State policy implementation of the inclusion in the General space training and re-training of teachers contributed to the increase in the number of pupils with special educational needs, allowed to expand as the quantitative and qualitative composition inclusive classes. Prospects of the further researches. There is an objective need for further study of the entire complex of issues related to the implementation of the right to education of children with disabilities. In particular, no special educational institutions, with the possibility of teaching a child with disabilities in comprehensive school essential not making are the problem of ensuring the continuity of rehabilitation. Keywords: Anthropology; Education.

\section{Cite this article as:}

Grygus, I, Nagorna, O. Nogas, A., \& Zukow, W. (2019). Anthropological providing educational services to children with special educational needs. Journal of Human Sport and Exercise, 14(4proc), S852-S866. doi:https://doi.org/10.14198//hse.2019.14.Proc4.48 


\section{ACTUALITY OF THEME}

The purpose of rehabilitation of children with special needs is the desire most comprehensive integration of the individual into society $[4,22,23]$. In the context of the issue of providing educational services to children with psychophysical development is becoming clearer and receptive society $[7,25]$. This long-term goal should implement, making physiotherapy support children with disabilities of various nosology. If we consider the rehabilitation of children with disabilities in general, we can identify several components of the process. In particular, it solve health and social problems. They are interdependent and can be regarded as complementary factors $[7,13]$.

Current status of solving the problem of the formation of the education system in Ukraine is characterized by versatility covered issues ambiguity of interpretation solutions to [6]. One of these dromos problems is needed to address a number of problems associated with teaching a child with special needs and differentiation of pupils in educational establishments [14,15]. This is because the problem is at the intersection of topical areas of pedagogy [5] psychology [12], sociology [4, 13] and physiology [1].

In educational circles there ever discussion on the performance of a feasibility learning. A complex issue is the differentiation of children in psychological, medical and pedagogical commissions on the choice of programs and learning, the educational institution.

Thus, it is urgent to study the system of teaching children with special needs the example of educational institutions. Exactly.

\section{THE AIM OF THE STUDY}

Explore formation of education for children with special educational needs.

\section{OBJECTIVES OF THE STUDY}

1. To conduct a systematic analysis of the scientific and technical literature on research.

2. Examine the network state inclusive schools in the city of Rivne.

3. Analyse the provision of educational services for children with disabilities in Rivne training and rehabilitation centre "Special Child".

4. Synthesize statistics and discover the dynamics of qualitative and quantitative nosology children with disabilities in schools.

\section{RESEARCH METHODS}

Theoretical analysis of the literature, summarizing statistics educational institutions of the city of Rivne.

\section{FORMULATION OF SCIENTIFIC PROBLEM AND ITS SIGNIFICANCE}

If we consider the younger person with special needs as a whole, it is clear understanding of multi-purpose support their rehabilitation. Much attention is paid in the process of teaching and rehabilitation and educational work, part of which primarily serve high-quality learning goals, the correction of the underlying disease and related disorders, prevention of secondary complications inherent in the implementation of creative, athletic ability and effectiveness of the remedial educational process [20, 23]. 
Legislative framework Ukraine presented a wide palette of documents to protect the child with disabilities to exercise their right to education. These include National Doctrine of Education of Ukraine, the Constitution of Ukraine, laws of Ukraine "On Education", "On Preschool Education", "Child Protection" concept of early rehabilitation of children with disabilities, Concept state standard special education. Implementation of the Constitution of Ukraine, the National Program "Children of Ukraine", the Law of Ukraine "On state social assistance to disabled from childhood and disabled children", "On the Rehabilitation of the Disabled in Ukraine" provides the solution of many pressing issues related to the support and protection child abuse and her family as a social institution. In these documents confirmed the right of equal access to education for all citizens of Ukraine regardless of their mental and physical capabilities.

The Law of Ukraine on the education of persons with disabilities singled out children with mental and physical violation, subject to inclusive education. In particular, depending on the type of abuse entails the following categories of children: hearing impaired (blind, deaf, with decreased hearing); visually impaired (blind, blind, with low vision); intellectual disabilities (mentally retarded, with mental retardation); with speech disorders; disorders of the musculoskeletal system; with a complex structure disorders (mentally retarded blind or deaf, deafblind, emotional and volitional disorders and children with autism.

The Law of Ukraine special education forms referred for special education, which provide that persons with disabilities can receive special education in special education institutions, special education departments, educational institutions integrated education, educational purpose in the forms provided by the Law Ukraine "On education".

Special education in Ukraine has vertical horizontal structure that provides differentiation in nosologies children and age groups $[17,21]$. Special educational institutions may be established for joint training people with different physical and (or) mental disabilities, unless it interferes with the successful assimilation of educational programs and training for such no medical contraindications [12, 17]. In Ukraine, created and operate special educational institutions, types and are determined according to the educational programs they have implemented, modalities for rehabilitation and aged learners $[7,20]$.

Accordingly, educational services for children with special needs are provided within special education institutions implementing programs of pre-school, primary education, are based on special education State standard $[6,7]$. Studies carried out in the inclusive, integrated, individual form $[14,15,16]$.

Another form of education for children with special needs are learning in training and rehabilitation centres, as indicated in Law of Ukraine special education. The main objectives are a few areas: the rights of children with complex disabilities to obtain the appropriate level of education according to their capacity, taking into account the individual characteristics of the complex rehabilitation.

Inclusive education to include a child with special needs in the general area to ensure her knowledge and skills, entry into certain experience according to individual and age characteristics $[14,16,18]$.

The Law of Ukraine on Education states that inclusive education is a system of educational services guaranteed by the state based on the principles of non-discrimination, taking into account the diversity of human and effective participation and inclusion in the educational process of all its members. 
The introduction of inclusive education in Ukraine long and difficult process, because solving a number of problems of formation of educational and rehabilitation support during education is complex and controversial.

Distinguish several problems implementing the process of inclusion: the unwillingness of society as a whole [12, 13], the existence of communication barriers [20], the lack of physical accessibility for persons with disabilities [3] has been established ways of continuity in the levels of training and rehabilitation of child support violations $[4,6]$, inadequate staffing and technical support inclusive schools $[3,16]$ psychological unpreparedness of the child and their family members to stay in the company healthy peers [19, 24, 27], differentiated criteria and contraindications for inclusive education [16, 28] and others.

It's worth noting that the conclusion psychological, medical and pedagogical consultations on forms of learning and the child in the educational setting is a recommendation [30]. The analysis showed that the commission did not include physical therapy specialists. And it is in their competence to determine the level of motor and physical readiness of the child to study in school.

Subject to the Law of Ukraine on Education for parents of a child with impaired is the ultimate choice of the institution. Research has shown that parents are not always able to objectively evaluate the opportunities and potential of the child, the need for correction and direction of development of the child [21].

If we analyse the provision of educational services for children with special needs in case of secondary schools. Exactly, we can observe positive dynamics of the process.

Thus, in the 2015-2016 academic years in 12 secondary schools were 23 inclusive classes, introduce that in 2016-2017 academic years in 14 schools of children with special needs enrolled 33 inclusive classrooms in 2017-2018 for 14 secondary schools had 41 inclusive class.

In Figure 1 shows the network inclusive secondary schools in Rivne during the 2015-2018 educational years.

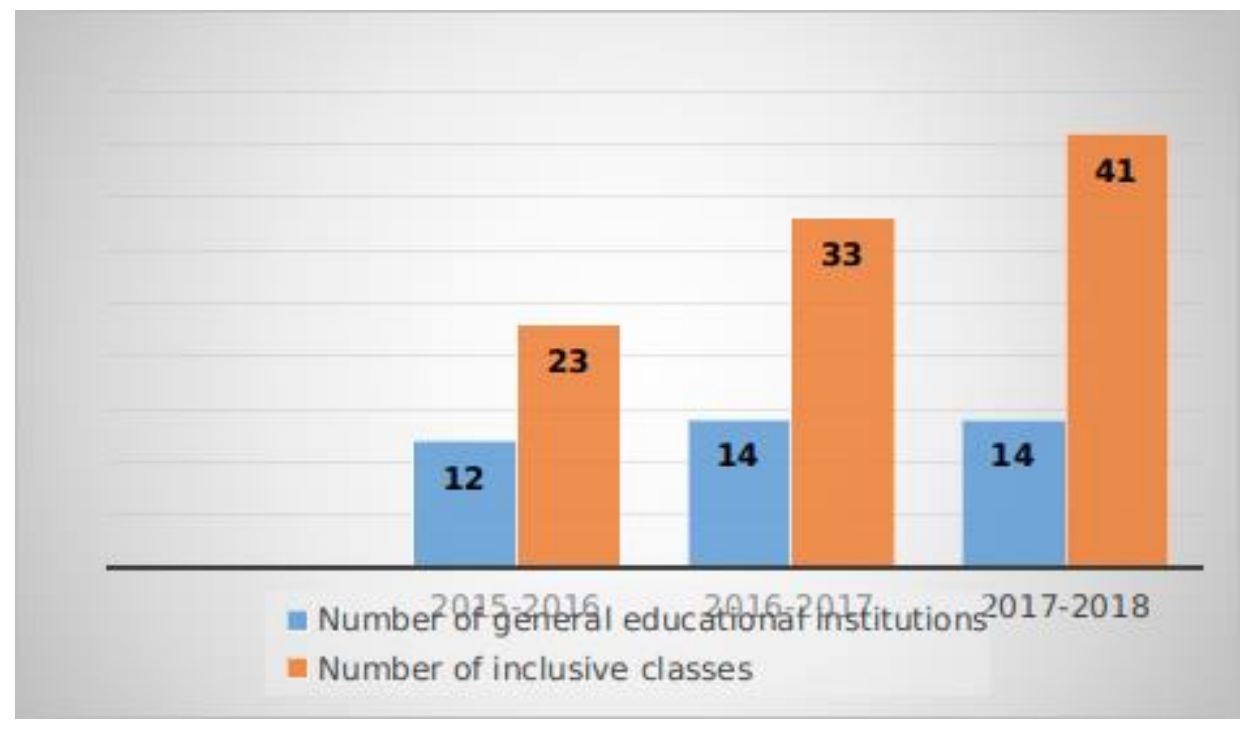

Figure 1. The United Nations Network of secondary schools in Rivne during the 2015-2018 educational years. 
It shows the positive dynamics of educational services for children with special educational needs in schools.

The analysis also require nosological category of students with special needs in inclusive classrooms. Quantity this category of children in schools of the city. Exactly during the academic years 2015-2018 are presented in Table 1.

Table 1. Number of children in different schools of nosology of Rivne during the 2015-2018 academic years

\begin{tabular}{|c|c|c|c|c|c|c|c|}
\hline $\begin{array}{c}\text { School } \\
\text { years }\end{array}$ & $\begin{array}{c}\text { Mental } \\
\text { retardation } \\
\text { increased }\end{array}$ & $\begin{array}{c}\text { Severely } \\
\text { impaired } \\
\text { speech }\end{array}$ & $\begin{array}{c}\text { Disorders of the } \\
\text { musculoskeletal } \\
\text { system }\end{array}$ & $\begin{array}{c}\text { Hearing } \\
\text { loss }\end{array}$ & $\begin{array}{c}\text { Reduction } \\
\text { of }\end{array}$ & $\begin{array}{c}\text { Mental } \\
\text { retardation }\end{array}$ & $\begin{array}{c}\text { Total } \\
\text { Students }\end{array}$ \\
\hline $\begin{array}{c}2015- \\
2016\end{array}$ & 19 & 12 & 7 & 5 & - & - & 43 \\
\hline $\begin{array}{c}2016- \\
2017\end{array}$ & 26 & 19 & 8 & 7 & 1 & 1 & 62 \\
\hline $\begin{array}{c}2017- \\
2018\end{array}$ & 29 & 24 & 10 & 8 & 2 & 1 & 74 \\
\hline
\end{tabular}

From Table 1 shows that during the 2015-2018 academic years the number of students diagnosed with mental retardation increased by 10 children $(33 \%)$ of hard speech disorders - 12 children $(100 \%)$, with disorders of the musculoskeletal system -3 children (43\%), hearing impaired -3 children $(60 \%)$ with visual impairments to 2 children (200\%) with mental retardation 1 child $(100 \%)$.

The dynamics of the number of students with disabilities in general education institutions of Rivne by 20152018 academic years are presented in Figure 2.

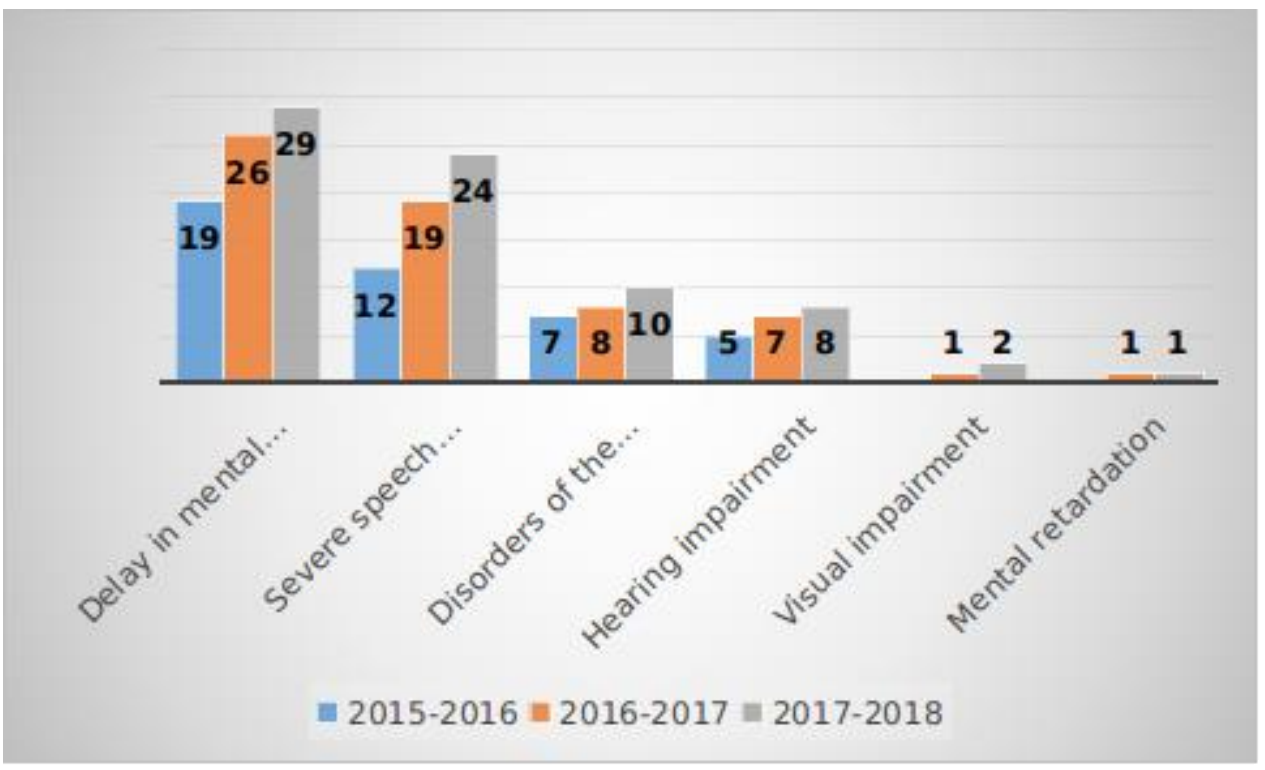

Figure 2. Change in the number of students with disabilities by $2015-2018$ academic years in secondary institutions of Rivne.

The analysis of quantitative and qualitative composition of inclusive classrooms, we conclude that children with special educational needs who are enrolled in inclusive classrooms for violations nosology been some 
imbalance. Thus, the advantage for inclusive education provided to students with cognitive and speech disorders. Almost half the number of children with musculoskeletal and hearing. A much smaller number of students with damage vision and mental retardation. Nis defined diagnoses such as autistic spectrum disorder and Down syndrome. Obviously, these violations to incorporate the category of violations intelligence.

However, these data are not sufficiently reflecting the situation objectively. Because the statistics take into account cognitive ability and thus the curriculum, which can be trained baby. Such diagnoses as cerebral palsy, Down syndrome, autism, mental retardation combine symptom disorders that require long-term, incremental correction.

However, the obvious is the fact that in terms of training in inclusive classrooms basic requirement is the development of a comprehensive child study program. The task of rehabilitation and correction of basic disease, its symptoms, complications of underlying disease should resolve in the educational and child protective regime assistants, correctional experts referred to in the conclusion of psychological, medical and pedagogical consultations.

Since the problem of integration of children with special needs into society is important for education Ukraine, Rivne multidisciplinary training and rehabilitation centre "Special Child" implements the objectives set out in Law of Ukraine on special education and aims to help the child with special needs to integrate into society.

In training and rehabilitation centre "Special Child" by students distinguish primary diagnosis on the basis of related disorders, the presence of a disability, the training program is recommended psychological, medical and educational advice. This differentiation facilitates efficient formation of a comprehensive rehabilitation program. It provides for the beginning and end of year consultation with a view to correcting complex programs of individual correctional medical and psycho pedagogical support of a child with severe disabilities through systematic and comprehensive diagnosis $[23,25]$.

Table 2 shows the number of children Rivne educational and rehabilitation centre "Special Child" during the 2015-2018 academic years, taking into account both the underlying disease and related symptoms.

An analysis of the data in Table 3, RNRTS "Special Child" for 2015-2018 academic years the number of students increased, with speech disorders in $28(17 \%)$, child, and with existing disabilities - $15(14 \%)$ students; with mental retardation - $10(15 \%)$ students, and with the existing disability in $35(88 \%)$ children; with CRA - $18(20 \%)$ of students without considering disability; the number of children with Down syndrome and disabilities are available -3 children (13\%).

Instead, the reduced number of students with physical illness - in $31(28 \%)$ of a child with disabilities available $-24(32 \%)$; with disorders of the musculoskeletal system - 21 children (18\%) with disabilities in 21 children (23\%); visually impaired - 12 children (15\%), disability 9 children (14\%); autism spectrum disorders -7 children (32\%), disability 9 children (45\%); children with diminished hearing - per child $(25 \%)$ on the basis of disability.

The difference changes the total number of students concerning students with disabilities for 2015-2018 academic years in the training and rehabilitation centre "Special child" are presented in Figure 3. 
Table 2. The number of children requiring correction of physical and (or) mental development RNRTS "Special Child" during the 2015-2018 academic years

\begin{tabular}{|c|c|c|c|c|c|c|c|}
\hline \multirow{2}{*}{\multicolumn{2}{|c|}{ The list of violations }} & \multicolumn{3}{|c|}{ Number of students } & \multicolumn{3}{|c|}{$\begin{array}{l}\text { Among them - } \\
\text { children with } \\
\text { disabilities }\end{array}$} \\
\hline & & $\begin{array}{l}2015- \\
2016\end{array}$ & $\begin{array}{l}2016- \\
2017\end{array}$ & $\begin{array}{l}2017- \\
2018\end{array}$ & $\begin{array}{l}2015- \\
2016\end{array}$ & $\begin{array}{l}2016- \\
2017\end{array}$ & $2017-$ \\
\hline \multicolumn{2}{|c|}{$\begin{array}{l}\text { Children with medical conditions (diseases of the } \\
\text { respiratory, nervous system, digestive system, } \\
\text { circulatory system, metabolic disorders) }\end{array}$} & 109 & 73 & 78 & 76 & 49 & 52 \\
\hline \multirow[b]{2}{*}{$\begin{array}{l}\text { Impaired } \\
\text { hearing }\end{array}$} & Deaf & - & - & - & - & - & - \\
\hline & $\begin{array}{l}\text { Children with diminished hearing } \\
\text { (complex infringement) }\end{array}$ & 4 & 4 & 4 & 4 & 3 & 3 \\
\hline \multirow[b]{2}{*}{$\begin{array}{l}\text { Visually } \\
\text { impaired }\end{array}$} & Blind & - & - & - & - & - & - \\
\hline & $\begin{array}{l}\text { Children with low vision (complex } \\
\text { infringement) }\end{array}$ & 82 & 68 & 70 & 63 & 54 & 54 \\
\hline \multicolumn{2}{|c|}{$\begin{array}{l}\text { Violations of the musculoskeletal system (cerebral } \\
\text { palsy, polio, congenital abnormality OPA, } \\
\text { traumatic damage to the spinal cord and brain, } \\
\text { skeletal disease) }\end{array}$} & 114 & 89 & 93 & 90 & 69 & 69 \\
\hline \multicolumn{2}{|c|}{ Children with mental retardation } & 92 & 100 & 110 & 50 & 52 & 47 \\
\hline \multicolumn{2}{|c|}{ Mentally retarded children } & 69 & 72 & 79 & 40 & 66 & 75 \\
\hline \multicolumn{2}{|c|}{ Autism spectrum disorders } & 22 & 13 & 15 & 20 & 10 & 11 \\
\hline \multicolumn{2}{|c|}{ Down syndrome } & 24 & 26 & 27 & 24 & 26 & 27 \\
\hline \multicolumn{2}{|c|}{$\begin{array}{l}\text { Speech disorders (alalia, aphasia, nasality, } \\
\text { dysarthria, dyslexia, dysgraphia, stuttering). }\end{array}$} & 161 & 172 & 189 & 107 & 118 & 122 \\
\hline \multicolumn{2}{|c|}{ Total children } & 161 & 172 & 189 & 107 & 118 & 123 \\
\hline
\end{tabular}

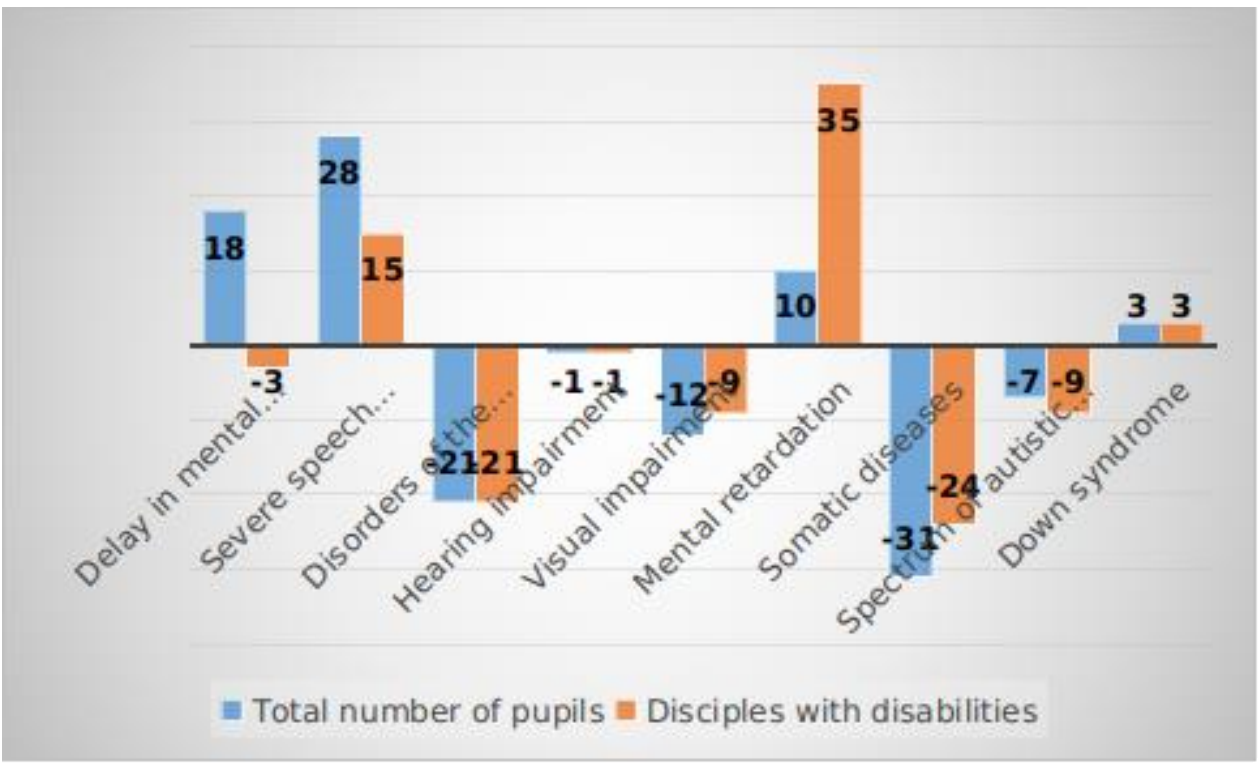

Figure 3. Dynamics of the total number of students concerning students with disabilities for 2015-2018 academic years in the training and rehabilitation centre "Special Child". 
It can be concluded that the number of students diagnosed with mental retardation and disability decreased available in $3(6 \%)$ of the child and with mental retardation by existing disability - increased by $35(88 \%)$ students. Clearly, students with intellectual disabilities in challenging RNRTS "Special Child" was over.

In Figure 4 presents summary data of the dynamics of the number of children with disabilities in general education institutions of Rivne and educational and rehabilitation centre "special child" during the 2015-2018 educational years.

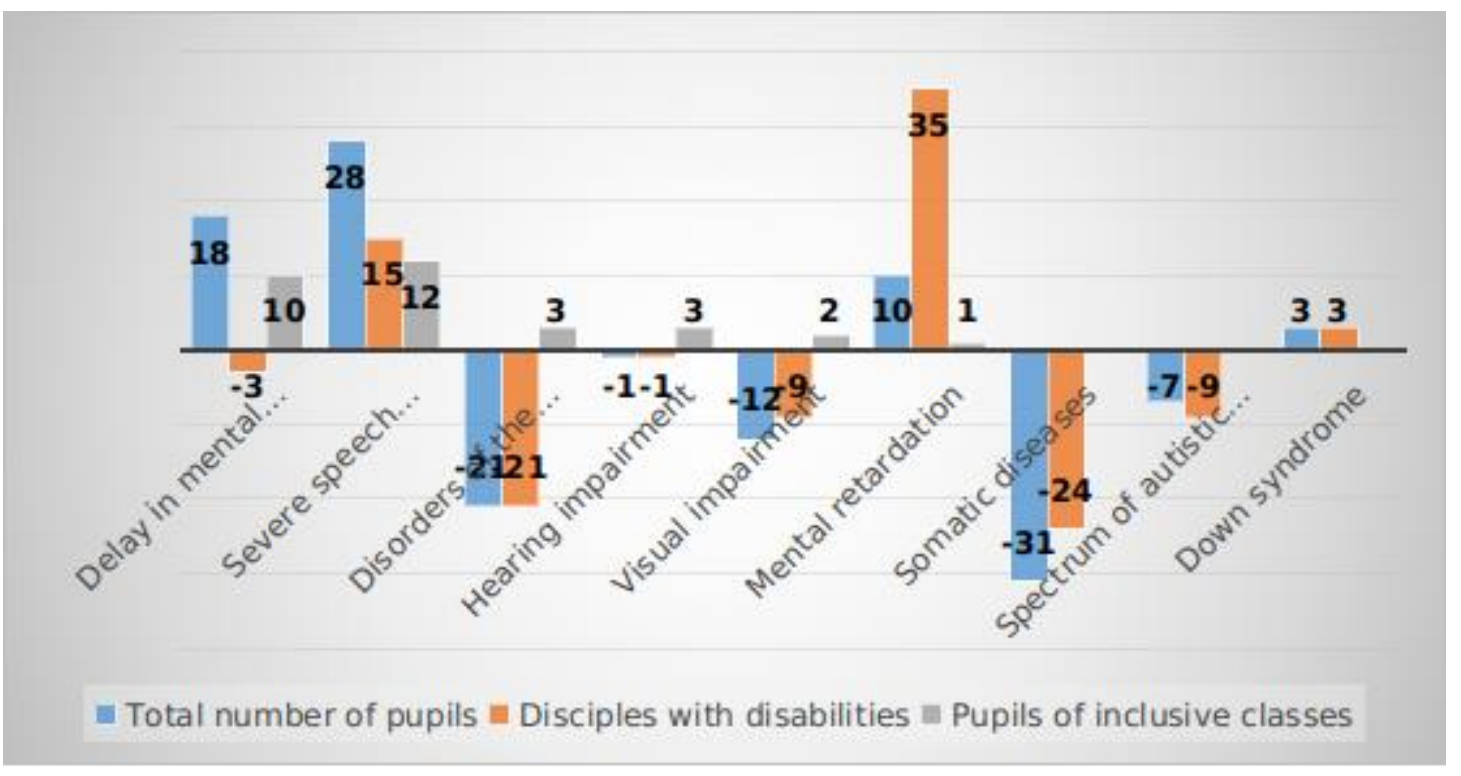

Figure 4. The dynamics of the number of children of different nosologies during 2015-2018 educational years in secondary schools and educational and rehabilitation centre "special child" in Rivne.

Summary certify that the NRC "Special Child" with the introduction of the inclusion of children with severe intellectual, complex disorders has increased. In inclusive schools taught children with preserved intellectual abilities. Students with Down syndrome, autistic spectrum disorder in secondary schools were observed. This analysis allows to investigate the processes of providing educational services to almost all categories of children with disabilities, which is essential in terms of comparison and generalization derived materials.

The effectiveness of the educational process, particularly for children with special educational needs, depending on the availability of qualified teachers and appropriate equipment of classrooms, school space and the surrounding area.

In this regard, the training of future teachers is related with the formation in their readiness to ensure corrective rehabilitation support. Given this need, the Ministry of Education, Youth and Sports of Ukraine recommended on September 2012/2013 academic year introduced in the educational process of higher educational institutions that train teachers, discipline "Fundamentals of inclusive education." Institute of Special Education, National Academy of Pedagogical Sciences of Ukraine developed and published application rate and Textbook "Fundamentals of inclusive education" [21]. Table 3 shows the performance of personnel and technical support of inclusive institutions in grade. Exactly in 2018 academic year. 
Table 3. Indexes human and technical support inclusive grade institutions of Rivne

\begin{tabular}{|c|c|c|c|c|c|c|}
\hline \multirow[t]{4}{*}{ Number } & $\begin{array}{c}\text { Secondary } \\
\text { school } \\
\text { (secondary } \\
\text { school) } \\
\end{array}$ & $\begin{array}{l}\text { Inclusive } \\
\text { classrooms }\end{array}$ & \multirow{3}{*}{\begin{tabular}{|c}
$\begin{array}{c}\text { Number of } \\
\text { pupils Plo }\end{array}$ \\
1 \\
1
\end{tabular}} & \multirow{2}{*}{$\begin{array}{c}\text { Training } \\
\text { program }\end{array}$} & $\begin{array}{l}\text { The availability of } \\
\text { technical equipment }\end{array}$ & $\begin{array}{c}\text { The presence of correctional } \\
\text { educators }\end{array}$ \\
\hline & \multirow{3}{*}{ School №4 } & $2-a$ & & & \multirow{3}{*}{$\begin{array}{l}\text { Ramp. Rail and } \\
\text { rehabilitation equipment }\end{array}$} & \multirow{3}{*}{$\begin{array}{l}\text { Practical psychologists, } \\
\text { rehabilitation, assistant child }\end{array}$} \\
\hline & & $5-b$ & & 4 & & \\
\hline & & $7-b$ & 2 & 3 & & \\
\hline 2. & School №5 & $3-b$ & $\begin{array}{l}1 \\
1 \\
1\end{array}$ & $\begin{array}{l}6 \\
3 \\
4\end{array}$ & Ramp & $\begin{array}{l}\text { Practical psychologists, } \\
\text { assistant child }\end{array}$ \\
\hline \multirow{2}{*}{3.} & \multirow{2}{*}{ School №6 } & $2-b$ & $\begin{array}{l}2 \\
1\end{array}$ & $\begin{array}{l}6 \\
3\end{array}$ & \multirow{2}{*}{$\begin{array}{l}\text { Wheelchair access, } \\
\text { exercise room }\end{array}$} & \multirow{2}{*}{$\begin{array}{l}\text { Psychologists, speech therapist. } \\
\text { Assistant child }\end{array}$} \\
\hline & & $3-b$ & 1 & 6 & & \\
\hline \multirow{4}{*}{4.} & \multirow{4}{*}{ School №8 } & $1-g$ & $\begin{array}{l}1 \\
1\end{array}$ & $\begin{array}{l}3 \\
4\end{array}$ & \multirow{4}{*}{$\begin{array}{l}\text { Ramps, handrails, room } \\
\text { psychologist }\end{array}$} & \multirow{4}{*}{$\begin{array}{l}\text { Practical psychologist, teacher } \\
\text { and speech therapist, assistant } \\
\text { child }\end{array}$} \\
\hline & & $2-g$ & 2 & 3 & & \\
\hline & & $3-d$ & 2 & 4 & & \\
\hline & & $5-g$ & 1 & 4 & & \\
\hline \multirow{5}{*}{5.} & \multirow{5}{*}{ School №9 } & $1-b$ & $\begin{array}{l}1 \\
2 \\
\end{array}$ & $\begin{array}{l}2 \\
6 \\
\end{array}$ & \multirow{5}{*}{$\begin{array}{l}\text { Ramps, } \quad \text { handrails. } \\
\text { Aerophones }\end{array}$} & \multirow{5}{*}{$\begin{array}{l}\text { Practical psychologist, teacher } \\
\text { and speech therapist, } \\
\text { surdopedahoh, assistant child }\end{array}$} \\
\hline & & $2-g$ & 1 & 2 & & \\
\hline & & $3-b$ & $\begin{array}{l}1 \\
1 \\
\end{array}$ & $\begin{array}{l}2 \\
3 \\
\end{array}$ & & \\
\hline & & $4-a$ & $\begin{array}{l}1 \\
1\end{array}$ & $\begin{array}{l}3 \\
2\end{array}$ & & \\
\hline & & $8-a$ & 2 & 2 & & \\
\hline \multirow{2}{*}{6.} & \multirow{2}{*}{ School №11 } & 4-h & 1 & 3 & \multirow[b]{2}{*}{ - } & \multirow{2}{*}{$\begin{array}{l}\text { Practical psychologists, } \\
\text { Assistant child }\end{array}$} \\
\hline & & $6-g$ & 1 & 5 & & \\
\hline 7. & School №12 & 5th & $\begin{array}{l}2 \\
1\end{array}$ & $\begin{array}{l}6 \\
3\end{array}$ & Ramps, handrails & $\begin{array}{ll}\text { Practical } & \text { psychologists, } \\
\text { assistant child } & \end{array}$ \\
\hline \multirow[b]{2}{*}{8.} & \multirow[b]{2}{*}{$\begin{array}{l}\text { School } \\
\text { №16. }\end{array}$} & $3 \mathrm{rd}$ & 1 & 4 & \multirow[b]{2}{*}{ Railings, rampant } & \multirow[b]{2}{*}{$\begin{array}{l}\text { Psychologist, speech therapist } \\
\text { rehabilitation, }\end{array}$} \\
\hline & & $5-b$ & 1 & 4 & & \\
\hline \multirow{2}{*}{9.} & \multirow{2}{*}{$\begin{array}{l}\text { School } \\
\text { №17. }\end{array}$} & $1-a$ & 1 & 4 & Ramps, handrails, room & Practical psychologists, \\
\hline & & $2-b$ & 1 & 6 & health & assistant child \\
\hline 10. & School №18 & $2-g$ & 1 & 4 & $\begin{array}{l}\text { Ramps, handrails in the } \\
\text { bathroom, exercise } \\
\text { room }\end{array}$ & $\begin{array}{l}\text { Practical psychologist, teacher } \\
\text { and speech therapist, assistant } \\
\text { child }\end{array}$ \\
\hline & & $1-b$ & 1 & 3 & & Practical $\quad$ psychologists, \\
\hline 11. & School №20 & 7 & 1 & 3 & Ramp & $\begin{array}{l}\text { correctional educator assistant } \\
\text { child }\end{array}$ \\
\hline & & $1-a$ & 3 & $\begin{array}{l}6 \\
3 \\
\end{array}$ & & \\
\hline & & $1-b$ & $\begin{array}{l}2 \\
1\end{array}$ & 6 & Ramps, handrails, & \\
\hline 12. & School №24 & $2-a$ & $\begin{array}{l}2 \\
1\end{array}$ & $\begin{array}{l}3 \\
6\end{array}$ & $\begin{array}{l}\text { cabinet psychologist, } \\
\text { speech therapist office }\end{array}$ & $\begin{array}{l}\text { Practical } \\
\text { assistant child }\end{array}$ \\
\hline & & $2-b$ & $\begin{array}{l}2 \\
1\end{array}$ & $\begin{array}{l}6 \\
3\end{array}$ & & \\
\hline & & 3-a & 2 & 3 & & \\
\hline
\end{tabular}




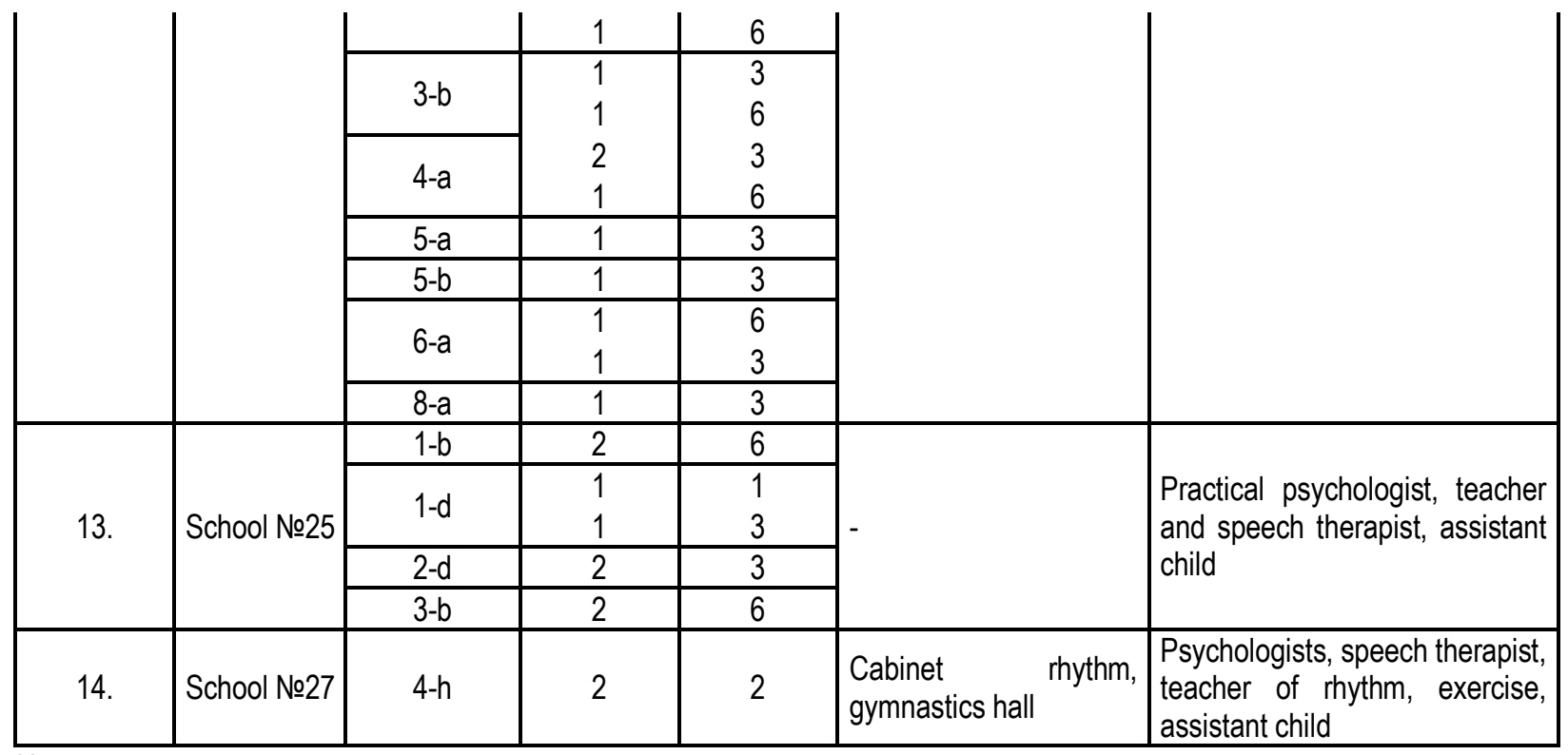

Notes:

The program for children with low vision - 1

The program for children with impaired hearing - 2

The program for children with mental retardation - 3

The program for children with musculoskeletal - 4

Training program for mentally retarded children - 5

The program for children with severe speech disorders - 6

Data analysis allows to conclude that the implementation of the state program regarding staffing inclusive education system is effective, but does not provide the full needs of schools in all states interdisciplinary rehabilitation team support a child with special needs. In particular, not all educational institutions properly equipped to meet the needs of the child and the full implementation of corrective maintenance; not organized specialized exercise rooms, not rehabilitation equipment, special furniture for students with disorders of the musculoskeletal system; tiflocorrection no means tiflopedagog; physical therapist is not available in all schools.

\section{CONCLUSIONS}

The analysis of the problem leads to the following conclusions: scientific and methodological sources analysed the effectiveness and appropriateness of various forms of educational services for children with special needs.

Analysis of inclusive classrooms demonstrates positive dynamics of the process and increase the number of students with impaired mental and physical development in schools.

Experience Rivne educational and rehabilitation centre "Special Child" confirms that due to the implementation of inclusive education in the institution increased the number of children with complex disabilities who are accompanied by mental retardation and disabilities are available. Therefore, special education institutions should be multidisciplinary, providing the child with special needs education and a proper correction and rehabilitation support. 
Due to purposeful state policy implementation inclusion in the general space training and retraining of teachers has increased the number of pupils with special educational needs, allowed to expand both quantitatively and qualitatively composition inclusive classes.

\section{PROSPECTS FOR FURTHER RESEARCH}

There is an objective need for further study of the entire complex of issues, related to the right to education for children with disabilities. In particular, no special educational institutions or with the possibility of teaching a child with disabilities in general education institutions not making significant is the problem of continuity of rehabilitation tasks.

\section{ETHICS APPROVAL AND CONSENT TO PARTICIPATE}

The research related to human use complied with all the relevant national regulations, institutional policies, and was in accordance with the tenets of the Helsinki Declaration. The study protocol was approved by the Ethical Committee of National University of Water and Environmental Engineering, Rivne, Ukraine.

During realization of tests, all participants provided informed consent and used all measures for maintaining anonymity of participants.

\section{AVAILABILITY OF DATA AND MATERIAL}

Authors are encouraged to / should make readily reproducible materials described in the manuscript, including new software, databases and all relevant raw data, freely available to any scientist wishing to use them, without breaching participant confidentiality. In any case, authors should make their new software, databases, application / tool described in the manuscript available for testing by reviewers in a way that preserves the reviewers' anonymity.

\section{CONSENT TO PUBLISH}

Not applicable.

\section{COMPETING INTERESTS}

The authors declare that they have no competing interests.

\section{CONFLICTS OF INTEREST}

All authors have no conflicts of interest to declare.

\section{FUNDING}

No funding. 


\section{AUTHORS' CONTRIBUTIONS}

IG, ON, LP participated in the design of this study. IG, ON, LP performed the statistical analyses. IG, ON, LP, WZ drafted the manuscript. IG, ON, LP, WZ were involved in data collection and/or made important intellectual contributions to the interpretation of data and the writing on paper. All authors critically revised and approved the final version.

\section{ACKNOWLEDGEMENTS}

Not applicable.

\section{REFERENCES}

Vygotskij L. S. K psihologii i pedagogike detskoj defektivnosti. Osnovy defektologii. [The psychology and pedagogy of children's impairments. Basics of speech pathologists]. S-Pb, M. Izd-vo Lan'. 2003. 101106. (In Russian).

Bohush A. M. Pidhotovka pedahohichnyx kadriv do realizaciyi pryncypu nastupnosti doshkil"noyi i pochatkovoyi lanok osvity. Humanizaciya navchal"no-vyxovnoho procesu: [Preparation of teaching staff to implement the principle of continuity of preschool and primary education units. Humanization of educational process]. Zbirnyk naukovyx prac" (specvypusk). Slov'yans"k. Vydavnychyj centr SDPU, 2007. 3-8. (In Ukrainian).

Voron M. V., Naida M. Inklyuzyvna osvita. Ukrayins"ki realiyi. [Inclusive Education. Ukrainian realities]. [Elektronnyj resurs]. Rezhym dostupu: ussf.kiev.ua/index.php?go=Inklus\&id=19 (Access 22.05.2018). (In Ukrainian).

Havrylov. O. V. Osoblyvi dity v zakladi ta social"nomu seredovyshhi. [Special Children in institutions and social environment]. Navchal"nyj posibnyk. Kam'yanec"-Podil"skyj. Aksioma, 2009. 308 p. (In Ukrainian).

Davydyuk M. O. Korekcijna pedahohika. Xrestomatiya. [Correctional Pedagogy. Reader]. Vinnycya. TOV Firma Planer. 2011. 205 p. (In Ukrainian).

Dehtyarenko T. M. Korekcijno-reabilitacijna robota v special"nyx doshkil"nyx zakladax dlya ditej z osoblyvymy potrebamy. [Correction and rehabilitation work in special pre-schools for children with special needs]. Navchal"nyj posibnyk. Sumy. VTD Universytets"ka knyha. 2008. 302 p. (In Ukrainian).

Dity z osoblyvymy potrebamy u zahal"noosvitn"omu prostori. Pochatkova lanka. [Children with special needs in a general area. The initial link]. Za redakciyeyu V. I. Bondarya, V.V. Zasenka. [Edited by V. Bondar VV Zasenko]. K. 2004. 152 p. (In Ukrainian).

Zakon Ukrayiny «Pro osnovy social"noyi zaxyshhenosti invalidiv v Ukrayini». [The Law of Ukraine "On the basis of social protection of invalids in Ukraine"]. Vidomosti Verxovnoyi Rady. 1991. №2. 252258. (In Ukrainian).

Zakon Ukrayiny «Pro oxoronu dytynstva». [The Law of Ukraine "On Protection of Childhood"]. Vidomosti Verxovnoyi Rady. 2001. №30. 142-150. (In Ukrainian).

Zakon Ukrayiny «Pro reabilitaciyu invalidiv v Ukrayini». [The Law of Ukraine "On the Rehabilitation of the Disabled in Ukraine"]. Vidomosti Verxovnoyi Rady. 2006. №2, № 3. 36-42. (In Ukrainian).

Zakon Ukrayiny «Pro special"nu osvitu (proekt)». [The Law of Ukraine "On special education (draft)"]. Ministerstvo osvity i nauky Ukrayiny. [Elektronnyj resurs]. Rezhym dostupu: www.mon.gov.ua (Access 22.05.2018). (In Ukrainian). 
Zasenko V. V. Do problemy osobystisnoho pidxodu u navchanni ditej z porushennyamy psyxofizychnoho rozvytku. Dydaktychni ta social"no-psyxolohichni aspekty korekcijnoyi roboty u special"nij shkoli. [The problem of personal approach in teaching children with mental and physical development. Teaching and social and psychological aspects of remedial work in special schools]. Nauk.-metod. zb. Vyp. 8. Za red. V. I. Bondarya, V. V. Zasenka. [Edited by V. Bondar VV Zasenko]. K. Nauk. Svit. 2006. 85-88. (In Ukrainian).

Zhyttyeva kompetentnist" osobystosti. [Life Competence personality.] Naukovo-metodychnyj posibnyk. Za red. L. V. Soxan, I. H. Yermakova, H. M. Nesen. [Edited by L. V. Soxan", I. H. Yermakov, H. M. Nesen]. K. Bohdana. 2003. 520 p. (In Ukrainian).

Inklyuzyvna osvita. Stan i perspektyvy rozvytku v Ukrayini. [Inclusive education: state and prospects of development in Ukraine]. Naukovo-metodychnyj zbirnyk. K. FO-P Prydatchenko P.M. 2007. 336 p. (In Ukrainian).

Intehrovane navchannya ditej z osoblyvymy potrebamy u prostori zahal"noosvitn"oyi shkoly. [Integrated education of children with special needs in the area of secondary school]. Dnipropetrovs"kyj oblasnyj psyxoloho-medyko-pedahohichnyj centr. Dnipropetrovs"k. 2005, 128 p. (In Ukrainian).

Kolupayeva A. A. Inklyuzyvna osvita: realiyi ta perspektywy. [Inclusive Education: Reality and Prospects]. Monohrafiya. K. Sammit-Knyha. 2009. 272 p. (In Ukrainian).

Kolupayeva, A. A., Savchuk L. O. Dity z osoblyvymy osvitnimy potrebamy ta orhanizaciya yix navchannya. [Children with special educational needs and organization of training]. Nauk.-metod. posib. MON Ukrayiny. NAPN Ukrayiny. In-t spec. pedahohiky. K. ATOPOL. 2011. 274 p. (In Ukrainian).

Lorman T., Deppler J., Harvey D. Inklyuzyvna osvita. Pidtrymka rozmayittya u klasi. [Inclusive Education. Support Diversity in the classroom: practical]. Prakt. posib. K. SPD-FO Parashyn I. S. 2010. 296 p. (In Ukrainian).

Lucenko I. Psyxoloho-pedahohichnyj suprovid dytyny z osoblyvymy potrebamy v umovax inklyuzyvnoho navchannya. Inklyuzyvna osvita. Stan i perspektyvy rozvytku v Ukrayini. [Psycho-pedagogical support of the child with special needs in terms of inclusive education. Inclusive education. State and prospects of development in Ukraine]. K. FOP Prydatchenko P.M. 2007. 20-33. (In Ukrainian).

Myronova S. P. Realizaciya korekcijnyx cilej u razi vykorystannya suchasnyx osvitnix texnolohij u special"nyx shkolax. [Implementation of remedial purposes in case of use of modern educational technologies in special schools]. Novi texnolohiyi navchannya. Nauk.-metod. zb. Kol. avt. K. Instytut innovacijnyx texnolohij i zmistu osvity MON Ukrayiny. 2008. Vyp. 53. 70-73. (In Ukrainian).

Osnovy inklyuzyvnoyi osvity. [Fundamentals of inclusive education]. Navch. metod. posib. MON molod" sportu Ukrayiny. Ny. NAPN Ukrayiny. In-t spec. Pedahohiky. Za zah. red. A. A. Kolupayevoyi. [Edited by A. A. Kolupayeva]. K. A.S.K. 2012. 308 p. (In Ukrainian).

Pal"chevs"kyj S. Akmeolohiya. [Acmeology]. Navchal"nyj posibnyk dlya studentiv vyshhyx navchal"nyx zakladiv. K. Kondor. 2008. 398 p. (In Ukrainian).

Petux O. V. Formuvannya zhyttyevyx kompetentnostej osobystosti z osoblyvymy osvitnimy potrebamy na zasadax pedahohiky zhyttyetvorchosti. [Forming life competencies of the individual with special needs on the basis of pedagogy of life making]. Aktual"ni pytannya korekcijnoyi osvity. Vyp. 10. Kamyanec"-Podil"skyj. Medobory. 2017. 233-241. (In Ukrainian).

Pidhotovka do shkoly ditej z osoblyvymy potrebamy v umovax sim'yi. [Preparing for school children with special needs in terms of family: parents tips]. Porady bat"kam. Za red. V. I. Bondarya, V. V. Zasenka. [Ed. V. Bondar VV Zasenko]. K. Nauk. svit. 2005. 256 p. (In Ukrainian).

Formuvannya zhyttyevyx kompetentnostej osobystosti z osoblyvymy osvitnimy potrebamy na zasadax pedahohiky zhyttyetvorchosti $v$ umovax akmeolohichnoho osvitn"o-reabilitacijnoho prostoru. [Formation of vital competence of the individual with special needs on the basis of pedagogy life 
making acmeological in terms of education and rehabilitation space]. Nauk.-metod. rekomendaciyi. kol. avt. Za zah. red. O. V. Petux. [Edited by O. V. Petux]. Rivne. 2017. 184 p. (In Ukrainian).

Kolupayeva A. A., Savchuk L. O. "Osoblyva» dytyna v navchanni. ["Special" child learning]. Za mat. nauk.-met. pos. Dity z osoblyvymy osvitnimy potrebamy ta orhanizaciya yix navchannya. Rivne. ROIPPO. 2010. 44 p. (In Ukrainian).

Svarnyk M. Inklyuzyvna osvita v Ukrayini. Poperednij analiz sytuaciyi. Prava ditej z osoblyvymy potrebamy na rivnyj dostup do yakisnoyi osvity. [Inclusive Education in Ukraine. A preliminary analysis of the situation. The rights of children with disabilities have equal access to quality education. K. 2001. 93 p. (In Ukrainian).

Shnajder V. I. Orhanizaciya indyvidual"noho navchannya: metodychni rekomendaciyi na dopomohu pedahoham ZOSh ta special"nyx zakladiv, reabilitacijnyx centriv, faxivcyam psyxoloho-medykopedahohichnyx konsul"tacij, pedahoham, psyxoloham, bat"kam. [Organization of individual training: guidelines to help school teachers and special schools, rehabilitation centers, professionals, psychological, medical and pedagogical consultations, teachers, psychologists, parents]. Kam'yanec"-Podil"s"kyj. Abetka-Nova. 2007. 148 p. (In Ukrainian).

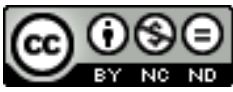

This work is licensed under a Attribution-NonCommercial-NoDerivatives 4.0 International (CC BY-NC-ND 4.0). 